\section{Social status and sex}

SIR - R. A. Beck's letter ${ }^{1}$ about artists' offspring provides interesting information, but fails to supply an appropriate theoretical framework against which his empirical findings could be tested. Beck's findings would have been much more instructive if he had explained why artists listed in the Who's Who in Art and The Annual Obituary might have more sons than daughters.

The appropriate framework would be the premises and the prediction of the Trivers-Willard hypothesis ${ }^{2}$ :

(1) As there is such a large difference in investment necessary for a live birth between males and females, variance in reproduction should be higher in males: more males should have more children than the median number and more males should remain childless than females.

(2) To the degree that parents' access to material resources positively affects the survival chances of offspring, parents' status should positively affect their reproductive success in relation to the population average. Then, because of males' greater variance in reproductive success, high status males should be reproductively more successful than high status females, while low status males should be reproductively less successful than low status females.

(3) The prediction is that under these conditions evolution should favour a bias in the sex ratio of offspring towards the male sex in high-status individuals, and a bias towards the female sex in low status individuals.

Whereas premises and prediction have been repeatedly verified for non-human populations, evidence for human populations is rare, not least because in census data children are usually documented only with their mothers.

Here are some other examples of male-biased sex ratio among élites. In a dataset of 1,014 male members of the US élite, born between 1860 and 1939 , drawn at random from American Who's Who, of those who gave complete information on their children's sex, there were 1,180 sons and 1,064 daughters, a sex ratio of 1.109 , still differing from the US average of 106 for this period $(P<0.005)$. In another dataset of 1,757 male members of the German élite, born between 1830 and 1939, drawn at random from the German Who's Who, of those who gave complete information on their children's sex, there were 1,473 sons and 1,294 daughters, a sex ratio of 1.138 , which differs from the mean sex radio of all live births in Germany 1872 1990 of $1.0512(P<0.001)$. (A frequent objection against sex ratio observations in élite samples refers to an eventual underreporting of daughters. Here, from the same sources, a dataset of 1,628 female members of the German élite, born between 1860 and 1945, was collected. The proportion of people who had not given complete information on their children's sex, was the same (about 25 per cent), as also the sex ratio of offspring among these élite females was the same (114.6) as among male élite members - the latter in conformity with the theory. It is therefore unlikely that there was a greater tendency to conceal a child's sex, if it was female.

Now, the Trivers-Willard hypothesis, strictly speaking, refers to whole population only insofar as they are single unsegmented marriage markets. Individuals who are considered of high status in the society as a whole may actually be low status on their proper marriage markets. The theory would then predict an unbiased or a female-biased sex ratio; this is what Boone ${ }^{3}$ found for the untitled gentry in the late mediaeval/early modern Portuguese genealogies.

From Great Britain there are two interesting observations with respect to this. First, fecundity data were obtained from biographies of 1,179 eminent British industrialists ${ }^{4}$ born between 1789 and 1925 , of whom only very few had a college education and almost none went to leading universities. These men and their families certainly did not form a closed marriage market, but belonged to a much larger middle-class marriage market, in which they may have been attractive competitors. The sex ratio of the children $(1,789$ sons and 1,522 daughters) is 1.1754 , well above the British average of $1.06(P<0.001)$.

Second, fecundity data were collected for 325 male members ( 60 per cent with a hereditary title) of the British élite, born between 1860 and 1939, drawn at random from the British Who's Who, whose father was mentioned in the same or earlier volumes of this source. For such men, admission to Who's Who was easier than for the rest; they may well be or have been less energetic and less forceful personalities than élite members without a prominent father. Of those who gave complete information on their children's sex, there were 241 sons and 249 daughters, a sex ratio of 0.968 , well below the average $(P<0.05)$.

\section{Ulrich Mueller}

ZUMA, Postfach 122155 ,

D-6800 Mannheim 1, Germany

1. Beck, R. A. Nature 356, 189 (1992).

2. Trivers, R. L. \& Willard, D. E. Science 179, 90-92 (1973).

3. Boone, J. L. Am. Anthropologist 88, 859-878 (1986)

4. Jeremy, D. J. (1984-86) (ed.) Dictionary of Business Biography. A Biographical Dictionary of Business Leaders Active in Britain 1860-1980. Vois 1-5 (Butterworths, London, 1984-86).
Molecular deconstructivism

SIR - Your readers should be aware of a cruel joke at the expense of the vocal chords of molecular biologists and the integrity of the English language that is currently being perpetrated by two otherwise respectable scientists ${ }^{1}$. In a paper in the official organ of the US National Academy of Sciences, Jürgen Brosius and Stephen Jay Gould propose to replace a large number of perfectly acceptable terms in molecular biology with a new "genomenclature" that will "keep pace with the levels and depth of analyzing and understanding genomic structure, function and evolution".

The basic element in their new dictionary is "nuon" (not to be confused with muon), which is supposed to denote "any stretch of nucleic acid sequence that may be identifiable by any criterion". (Note that this term does not cover invisible, nonexistent or imaginary DNA and RNA sequences.) In a clear fit of physics envy, Brosius and Gould coin such linguistic novelties as "naptonuons", "xaptonuons", "potonuons", "aptonuons" and "retropotonuons". Fortunately, for some unclear reasons, these authors decided not to rename all existing genetic elements, so that we were spared such words as "promonuon" (for promoter nuon), fipriflanuon (for five prime flanking nuon), or clatwinternuons (for class two intervening nuons). However, the paper does contain several nuonless novelties, such as potomass (for the obviously unsatisfactory genome) and xaptoproteins (for multifunctional proteins). One should also add that one of these authors is the co-inventor of such useful gems as "aptation", "exaptation" and "nonaptation"2, to which Brosius and Gould now add "potaptation". (I knew all along that something was missing.)

The story gets even more complicated since a potonuon can turn in time into either a naptonuon or a xaptonuon, and we therefore have "naptouonous potonuons" and "xaptonuonous potonuons". I can just imagine myself lecturing to my students on the coxII genes of legumes in this Newspeak: "The pea potonuon, although clearly poto-exaptive, ended up as a naptonuon because it could not be coopted into xaptonuonity." In the immortal words of Queen Victoria, "We are not amused."

Dan Graur

Department of Zoology,

Tel Aviv University,

Ramat Aviv 69978, Israel

1. Brosius, J. \& Gould, S. J. Proc. natn. Acad. Sci. U.S.A.
$89,10706-10710$ (1992).

2. Gould, S. J. \& Vrba, E. Paleobiology 8, 4-15 (1982) 